\title{
Changes in Non-Volatile Compounds and Extracts of Wines Due to Yeast Species and Fermentation Temperature
}

\author{
C. S. Ough and C. L. Winger \\ Department of Viticulture \& Enology, University of California, Davis, CA 95616 U.S.A. \\ Received April 1982
}

\begin{abstract}
The real reducing sugar-free extracts and the calculated extracts of wines vary significantly with fermentation temperature within the range of $12^{\circ}-21^{\circ} \mathrm{C}$. Relevant compositional changes are shown and discussed. The three yeasts used did not cause any significant difference in the calculated extracts. The conclusions were that any critical assessment of wine or juice amelioration based only on these forumulas would be subject to criticism.
\end{abstract}

In recent years the true nature of some California wines has been questioned by certain European countries. They have suggested that because the calculated extracts did not meet a certain set of criteria, water had been added to either the grapes or the wine. Most of the values used to establish these criteria were obtained from European grapes, which were probably ameliorated with sugar prior to fermentation and, in addition, fermented with a high level of insoluble solids and at warmer temperatures than now used in California wineries.

The calculated extract is obtained by subtracting from the sugar-free extract measurements all the compounds which are variable. The list of compounds used and some of the formulas commonly applied, are given in Table 1. These, in fact, are not all the compounds which can affect the extract and that are variable. Other compounds include nitrogen compounds which can vary in amount depending on the fermentation conditions (Ough et al., 1969). The phenol content can also vary depending on fermentation conditions such as temperature and skin contact (Ough et al., 1969).

TABLE 1

Calculated Extract Formulas Used.

Rebelein's short form calculated extract (Rebelein, 1971) $\mathrm{CE}=0.92 \mathrm{NE}-0.9 \mathrm{~T}-0.05 \mathrm{E}$

Gilbert's long form calculated extract (Gilbert, 1976): $\mathrm{CE}=\mathrm{NE}-1.18 \mathrm{TA}-\mathrm{M}-0.61 \mathrm{~L}-\mathrm{C}-0.95 \mathrm{~S}-0.37 \mathrm{~V}-0.61 \mathrm{G}$

Gilbert's calculated extract (Anon., 1977):

$\mathrm{CE}=\mathrm{NE}-1.18 \mathrm{TA}-\mathrm{M}-0.61 \mathrm{~L}-\mathrm{C}-0.37 \mathrm{~V}-0.06 \mathrm{E}$

Breitbach's calculated extract (Breitbach, 1978):

$\mathrm{CE}=\mathrm{NE}-1.18 \mathrm{TA}-\mathrm{M}-0.61 \mathrm{~L}-\mathrm{C}-0.37 \mathrm{~V}-0.01 \mathrm{E}-0.61 \mathrm{G}$

Where: $\mathrm{CE}=$ calculated extract

$\mathrm{NE}=$ non-reducing extract

$\mathrm{L}=$ lactic acid

$\mathrm{V}=$ volatile acid

$\mathrm{T}=$ titratable acid (as tartaric)

$\mathrm{E}=$ ethanol

$\mathrm{M}=$ malic acid

$\mathrm{G}$ = glycerol and 2,3-butanediol

$\mathrm{TA}=$ tartaric acid

$\mathrm{C}=$ citric acid

$\mathrm{S}=$ succinic acid

and all are reported in $\mathrm{g} / \ell$.

The purpose of this experiment was to ferment a grape juice of known purity and variety in order to determine if yeast species or temperature of fermentation affected the composition and the calculation of the extracts. Previously, Hannemann and Radler (1980) indicated that different species or strains of yeast caused very significant changes in the calculated residual extracts.

\section{MATERIALS AND METHODS}

Grapes and juice: Chenin blanc grapes were picked at mid-season from the Oakville vineyard of the University of California. They were at $22.5^{\circ}$ Brix, $8.5 \mathrm{~g} / \ell$ total acidity (as tartaric acid) with a pH of 3.35 and were crushed and pressed in a hydraulic basket press. The juice obtained would be equivalent to commercial free run juice. Approximately 600 litres of juice were collected. Sixty $\mathrm{mg} / \ell$ of sulphur dioxide was added and mixed in. The juice was settled at $15^{\circ} \mathrm{C}$ overnight with added pectinase, and racked the following morning into three containers, each holding 150 litres.

Yeast: Dry commercial yeast was used to inoculate the juices. The source of yeast was fresh samples from Universal Yeast Co. The three yeasts used were Montrachet (Saccharomyces cerevisiae), California Champagne (Saccharomyces bayanus) and Flor (Saccharomyces fermentati). These yeasts were rehydrated in $40^{\circ} \mathrm{C}$ water and then added to the respective containers. Each container received sufficient yeast culture to bring the viable cell count to about $10^{6}$ cells $/ \mathrm{m} \ell$. Two hundred $\mathrm{mg} / \ell$ of diatomaceous earth was also added.

Temperature: Three fermentation temperatures were selected for the experiment: $12^{\circ} \mathrm{C}, 16^{\circ} \mathrm{C}$, and $21^{\circ} \mathrm{C}$. This variation is not great, but covers the general range now used in California to ferment white juice. From previous work (Ough and Amerine, 1966, 1967 and Ough et al., 1969, 1972), it has been well documented that fermentation temperature affects the wine composition over these ranges.

Experimental design: The contents of the filled containers, with the individual yeast suspended in them, were each divided into 15 containers. Five of each were placed into each of the three temperature controlled rooms. Each of the five replicate samples was tested for ${ }^{\circ}$ Brix changes during fermentation. When the fermentations were complete (or as nearly so as they would go), they were racked several times and placed into a $-2^{\circ} \mathrm{C}$ room and allowed to stabilize for about two months, then carefully filtered into full containers and analysed. 
Analytical methods: The methods mainly used were those of Amerine and Ough (1980). The dried extract was done by drying under vacuum at $70^{\circ} \mathrm{C}$ until constant weight was achieved. The individual organic acids, except malic, were measured by the HPLC system described by Heymann (1980). The malic acid was measured enzymatically because of interferences in the HPLC system.

\section{RESULTS AND DISCUSSION}

The acid components are presented in Table 2, along with their statistical significance. The three yeasts caused significantly different results with all the acid components measured except citric and tartaric acids. However, the Champagne yeast replicates at $21^{\circ} \mathrm{C}$ fermentation temperature had started to undergo malolactic fermentation prior to getting them into the $-2^{\circ} \mathrm{C}$ room. If the $21^{\circ} \mathrm{C}$ Champagne samples are excluded from the results then the malic and lactic acid values are not significantly different. The same also holds for the $\mathrm{pH}$ and titratable acidity data. It seems that the two main factors which these yeasts affect are succinic and acetic acids. Montrachet definitely produced more succinic and less acetic acids in these tests than did the other two yeasts.

Looking at the temperature effects, the ones that were not biased by the partial malolactic fermentation of the Champagne at $21^{\circ} \mathrm{C}$ were citric, tartaric, succinic and acetic acids. There was a decline in the citric and tartaric acids with increasing fermentation temperature and an increase in succinic acid. The acetic acid levels were not significantly different. The titratable acidity, $\mathrm{pH}$, malic and lactic acids were all affected by the partial malolactic fermentation of the Champagne yeast samples at $21^{\circ} \mathrm{C}$.

Both with the Montrachet and Flor samples and the $12^{\circ} \mathrm{C}$ and $16^{\circ} \mathrm{C}$ samples, there were no significant differences other than those already identified - that is, succinic and acetic for the yeast, tartrate and succinic for temperature effects. The interaction data of yeast with temperature are shown in Figure 1. The Montrachet's succinic production is more enhanced by increase in temperature than that of the other two yeasts.

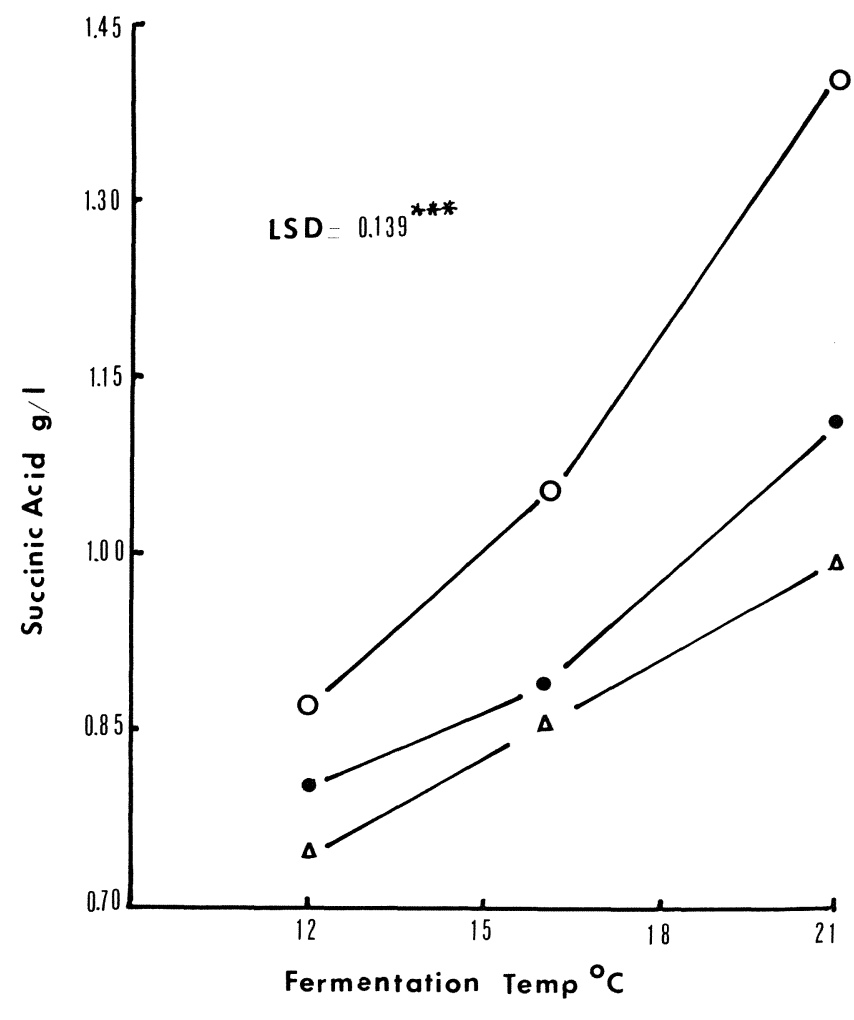

FIG. 1

Succinic acid production by Montrachet $(\bigcirc)$, Flor $(\bullet)$, and Champagne $(\triangle)$ yeasts at three fermentation temperatures.

Some of the major fermentation products are given in Table 3 along with the indicated significant differences in the means. The ethanol values are not significantly different if they are adjusted for the residual sugar values. The Champagne yeast did not quite ferment to dryness, and if the equivalent alcohol yields are considered, the differences are within experimental variation. Montrachet and Champagne produced less glycerol than the Flor yeast, and Montrachet produced only half as much 2,3-butanediols as the other two. The effects of the residual sugar in the Champagne yeast samples were spread over all the replicates fairly

TABLE 2

Acid Components in the Wines.

\begin{tabular}{|c|c|c|c|c|c|c|c|c|}
\hline Treatment & $\begin{array}{l}\text { Total acidity } \\
\mathrm{g} \text { tartaric acid } / \ell\end{array}$ & $\mathrm{pH}$ & $\begin{array}{l}\text { Citric } \\
\text { acid } g / \ell\end{array}$ & $\begin{array}{l}\text { Tartaric } \\
\text { acid } g / \ell\end{array}$ & $\begin{array}{l}\text { Malic } \\
\text { acid g/ } \ell\end{array}$ & $\begin{array}{l}\text { Succinic } \\
\text { acid } g / \ell\end{array}$ & $\begin{array}{l}\text { Lactic } \\
\text { acid } g / \ell\end{array}$ & $\begin{array}{l}\text { Acetic acid } \\
\mathrm{g} / \ell\end{array}$ \\
\hline \multicolumn{9}{|l|}{ Yeast } \\
\hline Champagne & $9.97_{b}$ & $3.34_{b}$ & $0.45_{\mathrm{a}}$ & $2.17_{\mathrm{a}}$ & $5.12 b$ & $0.86_{b}$ & $0.70_{\mathrm{b}}$ & $0.54_{b}$ \\
\hline Flor & $10.83_{\mathrm{a}}$ & $3.28 \mathrm{a}$ & $0.46_{a}$ & $2.09 \mathrm{a}$ & $6.42_{\mathrm{a}}$ & $0.94 b$ & $0.25 \mathrm{a}$ & $0.46_{b}$ \\
\hline $\operatorname{LSD}^{d}$ & $0.360^{* * *}$ & $0.033^{* * *}$ & N.S. & N.S. & $0.836^{* * *}$ & $0.080^{* * *}$ & $0.260 * * *$ & $0.117^{* * *}$ \\
\hline \multicolumn{9}{|l|}{ Temperature } \\
\hline $12^{\circ} \mathrm{C}$ & $10.59_{a}$ & $3.28 \mathrm{a}$ & $0.48_{\mathrm{a}}$ & $2.21_{\mathrm{a}}$ & $6.56_{a}$ & $0.80_{\mathrm{a}}$ & $0.29 \mathrm{a}$ & $0.42_{\mathrm{a}}$ \\
\hline $16^{\circ} \mathrm{C}$ & $10.65_{a}$ & $3.29_{\mathrm{a} . \mathrm{b}}$ & $0.47 \mathrm{a}$ & $2.09_{b}$ & $6.48 \mathrm{a}$ & $0.94 b$ & $0.29 \mathrm{a}$ & $0.41_{\mathrm{a}}$ \\
\hline $21^{\circ} \mathrm{C}$ & $10.08_{b}$ & $3.32_{b}$ & $0.44_{b}$ & $2.07 \mathrm{~b}$ & $5.06 \mathrm{~b}$ & $1.17_{\mathrm{c}}$ & $0.65 \mathrm{~b}$ & $0.43_{\mathrm{a}}$ \\
\hline $\mathrm{LSD}^{\mathrm{d}}$ & $0.360^{* * *}$ & $0.024^{* *}$ & $0.029^{*}$ & $0.106^{* *}$ & $0.836^{* * *}$ & $0.080^{* * *}$ & $0.260^{* * *}$ & N.S. \\
\hline
\end{tabular}

a, b, c Those values with different subscripts are significantly different.

${ }^{d}$ LSD means least significant difference between mean values at the level indicated.

$*, * *,{ }^{* *}$ Significant at 5,1 and $0.1 \%$ levels. 
evenly. Therefore, the ethanol decreases with temperature increases could be accepted. The glycerol (Ough $e t$ al., 1972) and 2,3-butanediols (Ough and Amerine, 1967) also behave as expected, increasing with increased fermentation temperature. However, the 2,3butanediols, as indicated in Figure 2, were produced less extensively by the Montrachet yeast, and the amounts were less affected by temperature.

TABLE 3

Fermentation Products in the Wines.

\begin{tabular}{|c|c|c|c|c|}
\hline \multirow[b]{2}{*}{ Treatment } & \multirow{2}{*}{$\begin{array}{c}\text { Ethanol } \\
\% \mathrm{v} / \mathrm{v}\end{array}$} & \multirow{2}{*}{$\begin{array}{l}\text { Glycerol } \\
\mathrm{g} / \ell\end{array}$} & \multicolumn{2}{|c|}{$\underset{\mathrm{g} / \ell}{\text { Butanediol }}$} \\
\hline & & & Levo & Meso \\
\hline \multicolumn{5}{|l|}{ Yeast } \\
\hline Montrachet & $12.53 \mathrm{a}$ & $5.58 \mathrm{a}$ & $0.28_{a}$ & $0.07 \mathrm{a}$ \\
\hline Champagne & $12.34_{b}$ & $5.58 \mathrm{a}$ & $0.58 \mathrm{~b}$ & $0.14_{c}$ \\
\hline Flor & $12.44_{a, b}$ & $6.31_{\mathrm{b}}$ & $0.54_{b}$ & $0.11_{b}$ \\
\hline $\operatorname{LSD}^{d}$ & $0.150^{* *}$ & $0.510^{* * *}$ & $0.051^{* * *}$ & $0.025^{* * *}$ \\
\hline \multicolumn{5}{|l|}{ Temperature } \\
\hline $12^{\circ} \mathrm{C}$ & $12.56_{a}$ & $4.90_{\mathrm{a}}$ & $0.34_{a}$ & $0.08_{a}$ \\
\hline $16^{\circ} \mathrm{C}$ & $12.45_{a, b}$ & $5.50_{b}$ & $0.44_{b}$ & $0.10_{a}$ \\
\hline $21^{\circ} \mathrm{C}$ & $12.29 \mathrm{~b}$ & $7.04_{c}$ & $0.61_{\mathrm{c}}$ & $0.14_{b}$ \\
\hline $\operatorname{LSD}^{d}$ & $0.206^{* * *}$ & $0.510^{* * *}$ & $0.051^{* * *}$ & $0.025^{* * *}$ \\
\hline
\end{tabular}

a.b,c Those values with different subscripts are significantly different.

${ }^{d}$ LSD means least significant differences between mean values at the levels indicated.

${ }^{*},{ }^{* *},{ }^{* *}$ Significance at 5,1 and $0.1 \%$ levels.

Other analyses concerned with the extract are given in Table 4. The reducing sugar is significantly different for the Champagne yeast as this yeast failed to ferment to dryness. This occurred at all temperatures. The potassium values were greatest for Montrachet and the least for the Flor samples. Proline was used to the greatest extent by the Montrachet, about $80 \mathrm{mg} / \ell$ less remaining than for the other two yeasts. Champagne yeast absorbed less phenols from the juice than did the other two yeasts. No significant differences were noted for the ash or alkalinity of the ash. The effects of tem-

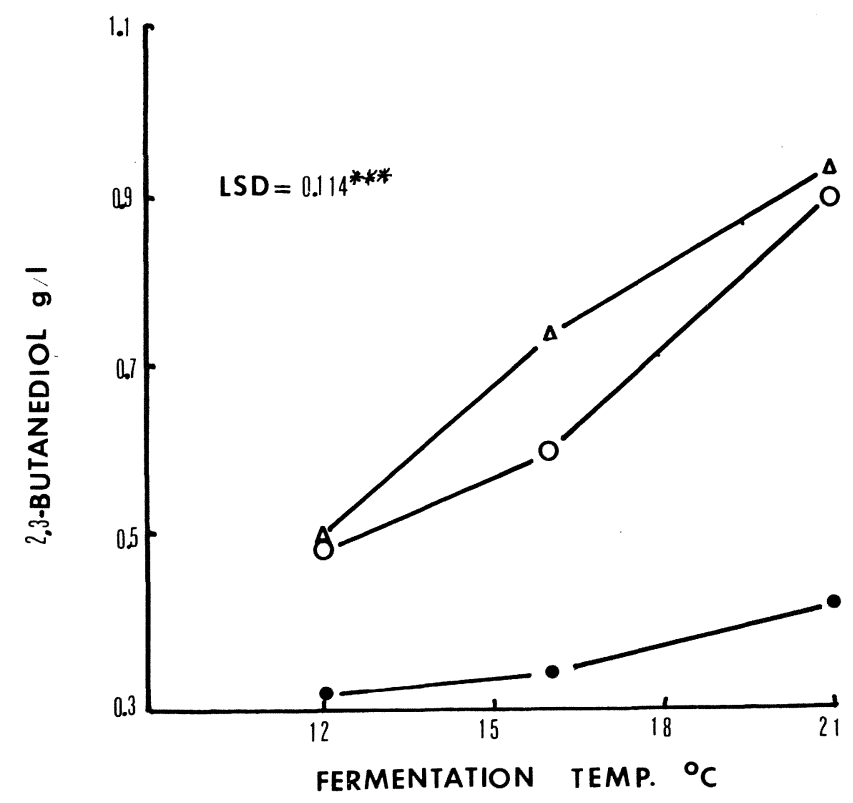

Fig. 2

2,3-Butanediol production by $\operatorname{Montrachet}(\bullet)$, Flor $(\bigcirc)$, and Champagne $(\triangle)$ yeasts at three fermentation temperatures.

perature were noted in only two instances. The potassium was lower for the $12^{\circ} \mathrm{C}$ samples and the proline lower for the $21^{\circ} \mathrm{C}$ samples. There were some significant interactions in these comparisons. The Flor yeast samples showed a definite effect of temperature on the potassium absorption where the others did not (Figure 3 ). Proline data graphed (Figure 4), for temperature effects on the individual yeasts indicate the ability for Montrachet yeast to assimilate more proline than the other two yeasts.

TABLE 4

Other Residual Compounds in the Wines

\begin{tabular}{|c|c|c|c|c|c|c|}
\hline Treatment & $\begin{array}{l}\text { Reducing } \\
\text { sugars } \\
\mathrm{g} / \ell\end{array}$ & $\begin{array}{l}\text { Potassium } \\
\mathrm{g} / \ell\end{array}$ & $\begin{array}{l}\text { Proline } \\
\mathrm{g} / \ell\end{array}$ & $\begin{array}{l}\text { Phenols } \\
\mathrm{g} / \ell\end{array}$ & $\begin{array}{c}\mathrm{Ash}^{\mathrm{c}} \\
\mathrm{g} / \ell\end{array}$ & $\begin{array}{l}\text { Alkalinity } \\
\text { of the ash } \\
\text { meq/ } / \ell\end{array}$ \\
\hline \multicolumn{7}{|l|}{ Yeast } \\
\hline Montrachet & $2.19 \mathrm{a}$ & $0.749 \mathrm{a}$ & $0.406_{a}$ & $0.219 \mathrm{a}$ & $1.493_{\mathrm{a}}$ & $17.9 \mathrm{a}$ \\
\hline Champagne & $4.03_{b}$ & $0.702_{b}$ & $0.487_{\mathrm{b}}$ & $0.232_{b}$ & $1.438_{\mathrm{a}}$ & $18.3_{\mathrm{a}}$ \\
\hline Flor & $2.21_{a}$ & $0.622_{c}$ & $0.485_{b}$ & 0.225 & $1.341_{\mathrm{a}}$ & $17.2_{\mathrm{a}}$ \\
\hline $\operatorname{LSD}^{d}$ & $1.37^{* * *}$ & $0.024^{* * *}$ & $0.015^{* * *}$ & $0.006^{* * *}$ & N.S. & N.S. \\
\hline \multicolumn{7}{|l|}{ Temperature } \\
\hline $12^{\circ} \mathrm{C}$ & $3.33_{a}$ & $0.636_{a}$ & $0.471_{\mathrm{a}}$ & $0.225 \mathrm{a}$ & $1.469 \mathrm{a}$ & $16.7_{\mathrm{a}}$ \\
\hline $16^{\circ} \mathrm{C}$ & $2.61_{a}$ & $0.716_{b}$ & $0.467 \mathrm{a}$ & $0.224_{a}$ & $1.405 \mathrm{a}$ & $18.1_{a}$ \\
\hline $21^{\circ} \mathrm{C}$ & $2.50_{\mathrm{a}}$ & $0.722_{\mathrm{b}}$ & $0.440_{\mathrm{b}}$ & $0.225_{a}$ & $1.397 \mathrm{a}$ & $18.6_{a}$ \\
\hline $\operatorname{LSD}^{d}$ & N.S. & $0.024^{* * *}$ & $0.015^{* * *}$ & N.S. & N.S. & N.S. \\
\hline
\end{tabular}

a, b.c Those values with different subscripts are significantly different.

${ }^{d}$ LSD means least significant difference between mean values at the level indicated.

c These sets of values calculated on pooled replicated samples for each yeast at each temperature.

${ }^{*},{ }^{* *},{ }^{* *}$ Significance at 5,1 and $0.1 \%$ levels. 


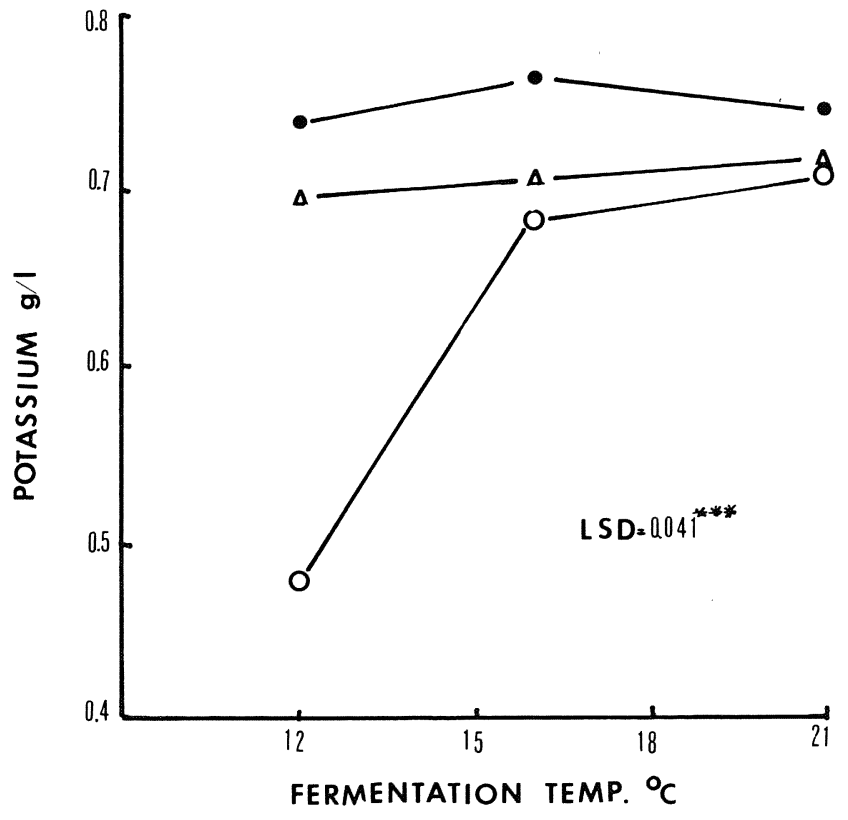

FIG. 3

Change in potassium content during fermentation at three fermentation temperatures by Montrachet $(\bullet)$, Flor $(\bigcirc)$, and Champagne $(\triangle)$ yeasts.

Table 5 gives the extract data, real and calculated by four formulas. The weighed extract was done on composite pooled samples of the replications of each yeast at each temperature. The overall value for the driedweighed extract was $20.23 \mathrm{~g} / \ell$ and the average value for the hydrometer extract was $21.98 \mathrm{~g} / \ell$. This is close to average values reported previously (Ough et al., 1969). With the dried-weighed extract, it is difficult to get consistent results. The calculations, therefore, were done using the hydrometer extract. The non-reducing extract showed a significantly lower value for the Champagne

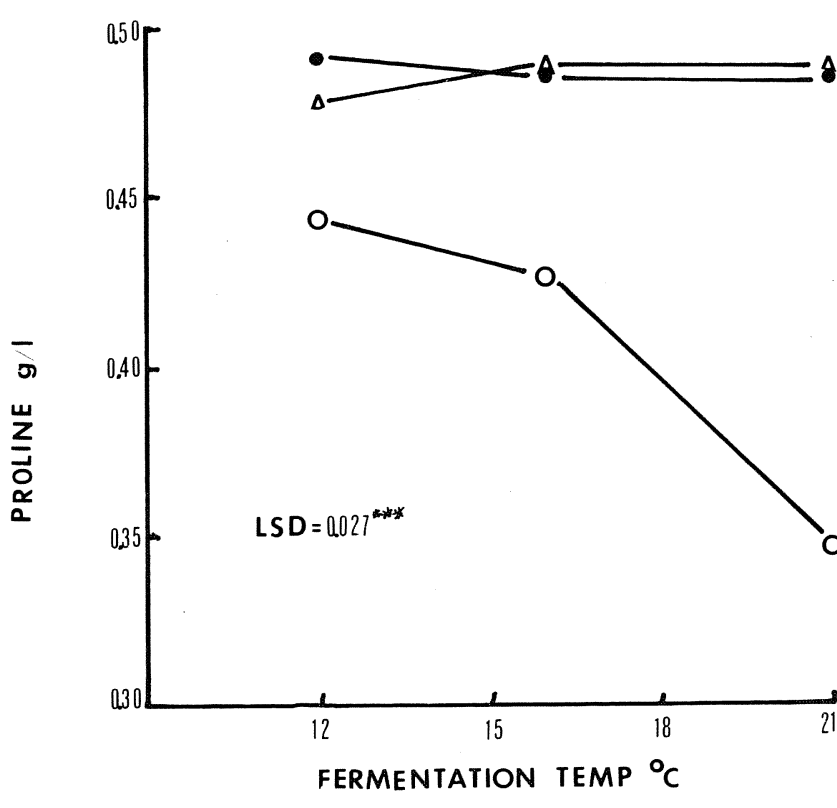

FIG. 4

Change in proline content during fermentation at three fermentation temperatures by Montrachet $(\bigcirc)$, Flor $(\triangle)$ and Champagne $(\bullet)$ yeasts.

yeast. None of the calculated extracts was significantly different for the various yeasts. The temperature caused a significant increase in the non-reducing extract at $21^{\circ} \mathrm{C}$. This was also seen in three of the four calculated extracts. All the calculated extracts and the real non-reducing sugar extracts are lower at the lower temperatures. This certainly would be expected for the calculated extracts, mainly because of the indicated loss in ethanol and titratable acidity with increasing temperature.

TABLE 5

Extracts and Calculated Extracts.

\begin{tabular}{|c|c|c|c|c|c|c|c|}
\hline \multirow[b]{2}{*}{ Treatment } & \multirow{2}{*}{$\begin{array}{l}\text { Weighed } \\
\text { extract } \\
\mathrm{g} / \ell\end{array}$} & \multirow{2}{*}{$\begin{array}{l}\text { Hydrometer } \\
\text { extract } \\
\mathrm{g} / \ell\end{array}$} & \multirow{2}{*}{$\begin{array}{l}\text { Non-reducing } \\
\text { extract } \\
\mathrm{g} / \ell\end{array}$} & \multicolumn{4}{|c|}{ Calculated extracts $\mathrm{g} / \ell$} \\
\hline & & & & $\begin{array}{l}\text { Rebelein } \\
\text { short form (11) }\end{array}$ & $\begin{array}{l}\text { Gilbert } \\
\text { long form (4) }\end{array}$ & $\begin{array}{l}\text { Gilbert } \\
\text { equation (2) }\end{array}$ & $\begin{array}{l}\text { Breitbach's } \\
\text { Equation (3) }\end{array}$ \\
\hline \multicolumn{8}{|l|}{ Yeasts } \\
\hline Montrachet & $19.57 \mathrm{a}$ & $21.55_{\mathrm{a}}$ & $19.36_{a . b}$ & $3.41_{\mathrm{a}}$ & $4.89 \mathrm{a}$ & $3.60_{\mathrm{a}}$ & $4.95 \mathrm{a}$ \\
\hline Champagne & $20.61_{a}$ & $22.49_{b}$ & $18.45 \mathrm{~b}$ & $3.11_{\mathrm{a}}$ & $5.05_{\mathrm{a}}$ & $3.84 a$ & $4.89 \mathrm{a}$ \\
\hline Flor & $20.50_{\mathrm{a}}$ & $21.89 \mathrm{a}$ & $19.68_{a}$ & $3.85_{\mathrm{a}}$ & $4.85_{\mathrm{a}}$ & $4.08 \mathrm{a}$ & $4.76_{\mathrm{a}}$ \\
\hline $\mathrm{LSD}^{\mathrm{c}}$ & N.S. & $0.72 * *$ & $1.04^{* * *}$ & N.S. & N.S. & N.S. & N.S. \\
\hline \multicolumn{8}{|l|}{ Temperature } \\
\hline $12^{\circ} \mathrm{C}$ & $19.83_{\mathrm{a}}$ & $22.09_{a}$ & $18.76_{a}$ & $2.75_{a}$ & $4.77_{\mathrm{a}}$ & $2.80_{\mathrm{a}}$ & $4.54 a$ \\
\hline $16^{\circ} \mathrm{C}$ & $20.15 \mathrm{a}$ & $21.75 \mathrm{a}$ & $19.13 \mathrm{a}$ & $3.07 \mathrm{a}$ & $4.78_{\mathrm{a}}$ & $3.46_{a}$ & $4.68 \mathrm{a}$ \\
\hline $21^{\circ} \mathrm{C}$ & $20.70_{\mathrm{a}}$ & $22.10_{\mathrm{a}}$ & $19.60_{\mathrm{b}}$ & $4.08_{\mathrm{b}}$ & $5.24_{\mathrm{a}}$ & $5.25 \mathrm{~b}$ & $5.73_{\mathrm{h}}$ \\
\hline $\operatorname{LSD}^{\mathrm{c}}$ & N.S. & N.S. & $0.55^{*}$ & $0.90^{* * *}$ & N.S. & $1.11^{* * *}$ & $0.64^{*}$ \\
\hline
\end{tabular}

a,b Those values with different subscripts are significantly different at the indicated level.

c LSD means least significant level.

$*, * *, * * *$ Significance at the 5,1 and $0.1 \%$ levels.

d Non-reducing extract is the hydrometer extract minus the reducing sugar.

( ) Refer to Literature Cited numbers. 
Some of the residual compounds not measured in these analyses are sulfate, phosphate, chloride and minerals other than potassium and nitrogen compounds, such as protein, amino acids (other than proline), peptides and others as well as the non-reducing sugars and other carbohydrate residuals. It has been shown (Ough et al., 1969) that phosphate and total nitrogen decrease with increasing temperature in the range used.

It is apparent that the use of these formulas in order to obtain calculated extract values, cannot be justified. The earlier exposé of Hannemann and Radler (1980) and the results obtained in this study indicate that the yeast and temperature effects on the juice composition during fermentation are such that any dependence on the calculated extracts for any significant purpose is highly questionable.

\section{LITERATURE CITED}

1. Amerine, M. A., and C. S. Ough. 1980. Methods for Analysis of Musts and Wines. John Wiley and Sons, New York, NY.

2. Anonymous. 1977. Restextrakt als Beurteilungskriterium. Weinwirtschaft. 113: 1416.
3. Breitbach, K. 1978. Restextrakt im Gutachterstreit. Weinwirtschaft. 114: 1507-11.

4. Gilbert, E. 1976. Uberlegungen zur Berechnung und Beurteilung des Restextraktgehaltes bei Wein.. Weinwirtschaft. 112: 118-27.

5. Hannemann, W., and F. Radler. 1980. Über den Einfluss verschiedener Hefestamme auf den Extraktstoffgehalt im Wein. Deutsche Lebensmittel-Rundschau. 76: 377-83.

6. Heymann, H. 1980. A Study of Succinic Acid Production in Wine. Master of Science Thesis. University of California, Davis.

7. Ough, C. S., and M. A. Amerine. 1966. Effects of Temperature on Winemaking. Univ. of California Exptl. Station. Bull. 827: 26p.

8. Ough, C. S., and M. A. Amerine. 1967. Studies With Controlled Fermentation. X. Effect of Some Fermentation Temperature on Some Volatile Compounds in Wine. Am. J. Enol. Vitic. 18: 157-64.

9. Ough, C. S., M. A. Amerine, and T. C. Sparks. 1969. Studies With Controlled Fermentations. XI. Fermentation Temperature Effects on Acidity and pH. Am. J. Enol. Vitic. 20: 127-39.

10. Ough, C. S., D. Fong, and M. A. Amerine. 1972. Glycerol in Wine: Determination and some Factors Affecting. Am. J. Enol. Vitic. 23: 1-5.

11. Rebelein, H. 1971. Qualitätseinstifung von Weinen, Allg. Deut. Weinfachztg. 107: 493-95, 520-24. 